\author{
Johan Sandahl \\ Stockholm University
}

DOI: http://dx.doi.org/10.5617/adno.8350

\title{
Opening up the echo chamber: Perspective taking in social science education
}

\begin{abstract}
Public discourse is increasingly polarised when it comes to contemporary political and controversial issues. The debating climate has been described as an "echo chamber" where we tend to find arguments supporting our own established truths rather than having our horizons broadened. Consequently, the challenge of taking the perspectives of others can be seen in classrooms when political discussions and topics surface within social science education. Teaching offers important arenas for deliberation, but classrooms can be as homogeneous as online filter bubbles, particularly in highly segregated urban school settings. One way of challenging students' one-sided views is to engage in, and practise, social perspective taking (SPT), a second-order concept engaging with different cultural and ideological understandings of political issues. This study examines two classroom interventions in an upper secondary school with the aim of contributing with empirical data about the components of SPT and how perspective taking can help students broaden their views on political issues. With a starting point in theory on SPT, students' interactions and reflections in the classroom, collected in written students' logs and follow-up interviews, are analysed. The results suggest that SPT segments can influence students' understanding of standpoints other than their own and increase their engagement in class, but that contextualisation is specifically important in this process.
\end{abstract}

Keywords: social science education, perspective taking, controversial issues

\section{Att öppna ekokammaren: Perspektivtagande i samhällskunskapsundervisningen}

\author{
Sammandrag \\ Debattklimatet i samhället har kommit att bli allt mer polariserat och de politiska \\ diskussionerna beskrivs som förda i "ekokammare” där vi med likasinnade hittar argu- \\ ment för våra egna synsätt, särskilt i kontroversiella frågor. Svårigheterna att ta andra \\ perspektiv än sina egna återfinns också i skolans undervisning, särskilt i ämnen som \\ samhällskunskap där aktuella och politiska diskussioner sker. Undervisningen erbjuder \\ här viktiga nycklar, inte minst att diskutera politiska och kontroversiella frågor i samtal, \\ men klassrum kan vara lika homogena i sin sammansättning som filterbubblor i digitala \\ miljöer. Ett sätt att utmana elevernas förgivettagande är att öva socialt perspektiv- \\ tagande - ett tankeredskap där eleverna i undervisningen tränas på att förstå olika \\ kulturella och ideologiska perspektiv på politiska frågor. Denna studie undersöker två \\ klassrumsinterventioner i en gymnasieklass och syftar till att empiriskt undersöka
}


aspekter av perspektivtagande och hur undervisningen kan formas för att öka elevernas förmåga att skifta perspektiv. Studien utgår från teori kring socialt perspektivtagande och undersöker klassrumsinteraktioner, elevers skrivna reflektioner och uppföljande fokusgruppsintervjuer. Studiens resultat visar att övningar som fokuserar på att skifta perspektiv ökar engagemanget $i$ undervisningen och påverkar elevernas sätt att se på innehållet, men att kontextualisering är ett av de viktigaste inslagen i socialt perspektivtagande.

Nyckelord: samhällskunskapsundervisning, perspektivtagande, kontroversiella frågor

\section{Introduction}

Public discourse is increasingly polarised when it comes to contemporary political and controversial issues. The modern democratic agora of social media has been described as an "echo chamber" where we tend to find our own comfort zones of established truths rather than having our horizons broadened (Bauman \& Obirek, 2015, p. 126). Consequently, the challenge of taking the perspectives of others can be seen in classrooms when political and controversial issues surface (Gehlbach \& Brinkworth, 2012). As such, schools have been highlighted as an important setting where adolescents' attitudes, experiences, knowledge, abilities and skills can be boosted in order to encourage active participation in democratic society - not least learning how to debate social issues from different perspectives (Campbell, 2012; Amnå, 2012, Parker, 2010a). This citizenship education can take place in many school subjects, but social studies subjects have been emphasised as important contributors to these processes (Parker, 2010b) and to social science education in particular (Christensen, 2011).

Teaching can offer important arenas for deliberation (Hess, 2009), where different perspectives and worldviews converge, but schools can be as homogeneous as online filter bubbles, particularly in highly segregated settings where students tend to find themselves in classrooms with peers from similar socioeconomic backgrounds (Bunar, 2010). One way of challenging students' onesided perceptions and thus encouraging citizenship education, is to engage in, and practise, perspective taking - a second-order concept that engages with different cultural and ideological understandings of political issues (Sandahl, 2015a). Perspective taking has been conceptualised as the process whereby a person discerns the feelings, thoughts and motivations of other agents, either between people in interaction (interpersonal) or at a more structural level (academic), where cultural, historical or political settings are in focus (Gehlbach et al., 2012; Gehlbach et al., 2015). In the literature, perspective taking has been emphasised as an important means to foster social relationships and contribute to building trust, but has also been criticised for the lack of empirical research (Pierce et al., 2013; Gehlbach et al., 2015; Brooks, 2009). Furthermore, most studies have been conducted in history education, where perspective taking revolves around 
understanding people in the past so as not to interpret their reflections through contemporary eyes (Lee \& Ashby, 2001; Seixas \& Morton, 2013; Hartmann \& Hasselhorn, 2008).

In regard to a more contemporary perception of perspective taking, defined as social perspective taking (SPT), many studies have concluded that, when people perform SPT tasks, it can significantly reduce stereotyping and negative judgements of other groups (Vescio et al., 2003; Todd et al., 2012; Wang et al., 2014), but that context is very important for outcomes (Tarrant et al., 2012; Skorinko \& Sinclair, 2013; Pierce et al., 2013). However, the vast majority of studies are based in psychology and conducted with adults in experimental settings, not students in educational contexts. In the literature, several studies call for additional empirical research focusing on classrooms in order to examine the components and processes involved in academic social perspective taking (Brooks, 2009; Gehlbach et al., 2012).

The aim of this article is to contribute with empirical data on these components and examine how perspective taking can help (or hinder) students in opening up one-sided opinions on political issues. Beginning with Endacott and Brooks' (2013) theoretical conceptualisation, in which SPT is understood as three elements: contextualisation, differential perspectives and affective connection, students' reflections in relation to two teaching interventions are analysed. These interventions were planned in collaboration between the researcher and a teacher and performed in a year 10 social science class with the aim of promoting their SPT abilities. Two research questions are posed:

1. What kinds of reflections does social perspective taking invoke in students, and how can these be understood in relation to the three elements?

2. What teaching practices promote the development of social perspective taking?

\section{Cultivating perspective taking in education}

A benchmark of Western democratic schooling is the assumption of the dual responsibility of developing young people's knowledge and abilities and instilling students with the shared values of democracy (Gutmann \& Ben-Porath, 2015). This responsibility is referred to as citizenship education. The concept involves attitudes, experiences, knowledge, abilities and skills that students need in order to become active participants in a democratic society (Campbell, 2012, p. 1). Historically and currently, the most prominent subject in schools with responsibility for contributing to citizenship education is social studies (Parker, 2010a). It is comprised of different academic disciplines, but the common core is human activity in past and present societies, and students are taught to inquire about social issues and to consider the role of values in these issues (Barton, 2011). In 
the Nordic and many other European countries, social science education, with its focus on contemporary politics, has been emphasised in particular (Christensen, 2011).

A specific target for teaching has been to address controversial and political issues in the public debate and through these issues to engage students in critical thinking about both local and global topics (Barton \& McCully, 2007; Misco, 2012). In many cases, there has been a reluctance to address such issues among policymakers and teachers due to fear of generating partisanship and politicisation (Alongi et al., 2016) but in social studies education, both advocates of deliberative education (Hess, 2009; Englund, 2006) and of disciplinary education (Sandahl, 2015a; Barton, 2017) have argued that perspective taking is at the centre of critical thinking about societal issues.

Perspective taking has been the focus of numerous studies in social studies education, but most have examined historical perspective taking (Davis et al., 2001; Brooks, 2009). With the aim of reducing students' presentism, it has been described as one of the most important second-order concepts, focusing on students' ability "to see through the eyes of people who lived in times and circumstances sometimes far removed from our present-day lives" (Seixas \& Morton, 2013, p. 138). Studies in the field have mainly been concerned with academic perspective taking, i.e., understanding other people's ideas rather than having empathy for other individuals (for distinctions, see below), focusing for instance on the challenging task of teaching students to avoid equating the past with the present, i.e., contextualising the studied phenomena (Lee \& Ashby, 2001; Hartmann \& Hasselhorn, 2008). As such, perspective taking has been highlighted as important in preparing students to be active and engaged citizens. Barton and Levstik (2014, p. 216) argue that students must practise removing themselves from their own viewpoint for long enough to realise that others take different perspectives - frequently just as valid as their own. As clearly indicated in Barton and Levstik's argument, there are many crossroads between the historical notion of perspective taking and its more contemporary interpretation. Sandahl (2015a; cf. Barton, 2017) argues that, instead of reconstructing others' values, beliefs and agendas in the past, perspective taking in social sciences focuses on contemporary ideological and cultural systems of thought that differ from that of the student. In social science education, the term social perspective taking (SPT) has been used to distinguish it from history education.

In both historical and social perspective taking there has been a critique that the concept's importance for the classroom remains at the level of theory (Brooks, 2009). However, some studies during the last decade have conducted empirical work aimed at understanding the outcomes of different kinds of social perspective taking. Several studies, particularly in psychology, have shown that SPT elements have the potential to significantly reduce stereotyping and negative judgements of other groups (Vescio et al., 2003; Todd et al., 2012; Wang et al., 2014). Other scholars have been more cautious and have described context as very important: 
strong personal beliefs or group identities can in fact increase stereotyping (Tarrant et al., 2012; Skorinko \& Sinclair, 2013). Pierce et al. (2013) showed that competition versus collaboration had a huge impact on results. When people performed SPT tasks in a competitive environment, such as negotiations, unethical behaviour and stereotyping were more common. Yet, most studies within this field have been conducted with adults in experimental settings and not in educational contexts.

In important contributions to social studies education, Gehlbach (2004) and Gehlbach et al. (2015) have shown that getting students to practise SPT contributes to conflict resolution and empathy, and that students develop more positive relationships with those who hold other beliefs. Many studies focus on students' interpersonal SPT, i.e., understanding other people in class or at school, rather than academic SPT, in which cultural, ideological and historical settings and contexts are the focus (Walker et al., 2013; Chichekian \& Shore, 2017). Gehlbach et al. (2012, p. 202) conclude that demonstrating that SPT is important is not enough and that there is a need to "engage in the SPT process if we are to improve SPT for those within school communities", something that several scholars identify as missing from previous research (e.g., Brooks, 2009; Gehlbach et al., 2012).

\section{Theoretical framework: Academic social perspective taking}

In the social sciences, perspective taking has been described as social and conceptualised as the process of an agent discerning the thoughts, feelings and motivations of other agents (Gehlbach et al., 2012; Gehlbach et al., 2015). Theoretically, social perspective taking (SPT) can be understood as one of the most important mechanisms in fostering social relationships and building trust between different groups in society. The theory differentiates between interpersonal SPT, i.e. between individuals who are sharing their different ideas and lines of thought, and academic SPT, which is more focused on the historical, cultural and political agents and phenomena that are being studied. In many cases, these kinds of perspective taking can overlap since individuals are linked to structures in society: for example, one politically active student might be connected to a certain party with its system of thought. Yet, the individual perspective is more easily accessible and can be examined directly through interpersonal exchanges (Gehlbach, 2011; Gehlbach \& Brinkworth, 2012; cf. Hess, 2009). Furthermore, personal ideals are often intertwined with understandings of societal issues in a political identity (Huddy, 2001; Ross, 2019). This study focuses on academic SPT, not the interactions between students about their own ideas but their reflections in relation to historical, cultural and political agents and/or phenomena.

As presented in the literature review, there has been a critique of research for being too theoretical, arguing for the benefits of SPT in teaching (see Brooks, 
2009). However, the theoretical work displays very different theoretical understandings of what perspective taking means and how its components should be described. An important discussion relates to the role of empathy, with some arguing that perspective taking does not include feeling for or sympathising with other actors, but rather focuses on cognitive aspects (Lee \& Ashby, 2001; Seixas \& Morton, 2013, p. 155). Other scholars have been critical of teaching that solely emphasises cognitive aspects and argue for bringing in students' own experiences, personal beliefs and emotions - otherwise, teaching risks becoming "meaningless" (Sandahl, 2015c; cf. Barton, 2009). Endacott and Brooks (2013) bring these viewpoints together and argue that perspective taking in social studies education relates to three different, but related elements. First, a perspective is rooted in a particular contextual setting that needs to be understood, i.e., cultural, ideological or historical ways of thinking. Second, that those perspectives can be understood through a particular agent's way of thinking and, third, that these perspectives are affective in the sense that they are based on a "connection made to one's own similar yet different life experiences” (Endacott \& Brooks, 2013, p. 43). In this case, the researchers argue for not limiting perspective taking to cognition and suggest that a combination of these elements can provide a more powerful experience.

Endacott and Brooks (2013, p. 44) visualise their conceptualisation in a Venn diagram, in which they suggest possible logical relations between these elements. In this study, an adapted version is used. The first element represents contextual aspects of perspective taking, e.g. relating social issues to a specific cultural, historical and ideological setting. The second element represents different perspectives from different agents, e.g. that a social issue can be considered from different points of view. These two cognitive elements are closely linked to the ways in which historians and social scientists try to make sense of past and present social issues (Seixas \& Morton, 2013; Barton, 2017). The third element is less cognitive and relates to the affective sides of perspective taking, i.e. that social issues are value-laden and therefore invoke emotions in individuals, often related to students' own experiences and beliefs (cf. Sandahl, 2015a, 2019; Barton, 2009; Alsop, 2016). In line with Endacott and Brooks (2013, p. 44; cf. Sandahl, 2019), I argue that this combination of disciplinary and lifeworld approaches has the potential to promote both intrinsic goals (qualification of knowledge and abilities in the subject) and extrinsic goals (development of understanding, skills, and dispositions from which an individual might benefit as a citizen). This incorporation of the lifeworld has been underscored as important in order to enhance students' interest and meaning making in citizenship education (Barton, 2009; Parker, 2010a; Sandahl, 2015c). A visualisation of the theoretical understanding of Academic SPT employed in this study is shown in Figure 1. 


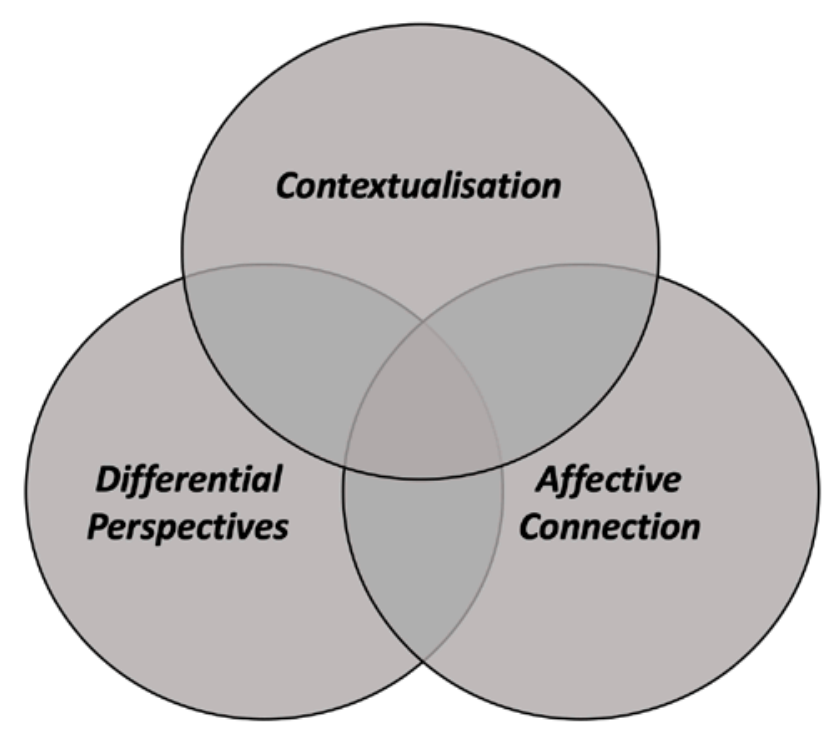

Figure 1. Visual conceptualisation of academic social perspective taking (adapted from Endacott \& Brooks, 2013, p. 44)

The three elements offer a way to operationalise social perspective taking and thereby analyse how students display these elements in their reflections both during and after discussions and tasks. Furthermore, the elements provide a theoretical way to discuss the interrelations between the elements and how they might hinder or enable students' understanding of political issues.

\section{Method and material}

This study focuses on two classroom interventions within a broader research project at an upper secondary school. In this project, the researcher followed a class of year 10 (16-17 years old) social science students as they worked through a module on Western welfare systems. This module was designed to develop students' disciplinary thinking, in particular their ability to use second-order concepts such as perspective taking (Sandahl, 2015a, 2015c; Barton, 2017). The lessons were planned in collaboration between the researcher and the social science teacher. Content material and specific tasks were laid out in alignment with curriculum requirements to promote students' ability to perform the tasks of analysing social issues and critically reviewing different perspectives (Swedish National Agency for Education, 2011, p. 2). The planning of the interventions was not structured or informed by theory (i.e., the three elements of SPT) per se, but tried to focus on bringing in contextual knowledge and offering ways to shed light on different perspectives.

The core content of the welfare state was considered appropriate since it can be considered a political expression of moral conceptions and values (Kildal \& Kuhnle, 2005); i.e., it is a contested and sometimes controversial political issue. 
Before teaching began, the teacher and the researcher mapped out some of the challenges that students faced in regard to perspective taking. The teacher had observed that many of the students had strong political beliefs that they brought to class - beliefs that sometimes clouded their ability to analyse societal issues. In order to gather more information on students' positions in regard to the welfare state, a projective elicitation task (Barton, 2015) was performed, in which students were asked to respond to a social-democratic and a liberal argument on the best welfare regime. The results (published in Sandahl, 2019) demonstrated that students in general had difficulties in recognising the difference between politics and the study of politics, i.e., they responded politically rather than analytically thus giving support to the teacher's notion of the student group. ${ }^{1}$

Furthermore, in students' answers, two different aspects were noted. First, a lack of knowledge about welfare systems other than their own, resulting in stereotyping other welfare systems as "bad", "underdeveloped" or even "evil". Second, and connected to the first aspect, there was an inability to understand the cultural and ideological contexts of other welfare regimes, i.e., different emphases on societal values. Taking a point of departure in this analysis, the researcher and teacher planned two interventions designed to foster students' social perspective taking. The first was a task in which pairs of students compared different countries belonging to what Esping-Andersen (1990) labels as liberal, conservative and social-democratic welfare regimes, here called the "comparing context task". The second intervention, called "the fishbowl", was suggested by the teacher, and took the form of a debating task in which students assumed different roles with particular ideological perspectives. "The fishbowl” had a significant competitive form, which was discussed during the planning in regard to previous findings (e.g., Pierce et al., 2013), but the teacher had good experiences of the method from prior teaching and it was decided to include it. From a research perspective, it was interesting to discover whether this study would have the same outcome in the classroom as previous findings from experimental settings.

Both interventions are described in detail in the results section below. Importantly, the tasks were not designed to promote interpersonal SPT (i.e., exchanges between students about their own ideas of the welfare system), but on academic SPT where they focused on external content (cf. Barton, 2015).

\section{Observations, student discussions and focus groups}

The data set for this study consisted of classroom observations and recordings, students' logs and follow-up interviews in focus groups. As such, the design and methods were based on the qualitative and interpretative tradition of educational ethnographic research (Delamont, 2011; Cohen et al., 2011), attempting to

\footnotetext{
${ }^{1}$ Students' positioning in the study (Sandahl, 2019) showed strong support for the Swedish welfare system. This is not surprising since general support for the welfare state is strong in Sweden (Svallfors, 2011) and previous results show that, overall, students in different contexts share the same sentiments about Sweden as a socialdemocratic welfare state (see Sandahl, 2015b).
} 
understand teaching and students' social interactions in a setting that has been characterised as "a messy place, full of contradictions, richness, [and] complexity” (Cohen et al., 2011, p. 186). Even though lessons were planned together with the teacher, the researcher did not take an active role during the two interventions. The tasks were introduced and managed by the teacher, and the researcher was aiming to be a detached observer. However, spending time with students for a number of weeks made it impossible to remain completely detached. During the interventions, occasional questions were answered but interactions were limited.

Being an observer in class has its challenges. In classrooms, many things happen simultaneously, and students' attention is not always directed towards the tasks they have before them. A strategy for taking field notes was to focus on the content matter that students were discussing, i.e., trying to filter out comments, interactions and events that were not related to the specific task that students had been set. In accordance with ethnographic research, the observations were supported by audio recordings of group discussions during the two interventions. These recordings were not transcribed for all of the groups or in full, but limited to the groups that it was manageable to observe and situations that were of particular interest. Furthermore, in order to capture students' individual experiences of the interventions, they were asked to write individual logbooks at the end of each lesson. All 32 logs were shared with the researcher digitally. In order to triangulate the outcomes of the interventions, data was supplemented by focus group interviews with the students (Vaughn et al., 2012). These were conducted in order to acquire specific information in a relatively short period of time. By using the field notes, it was possible to elicit, or stimulate, specific responses in relation to what happened during the interventions. The focus groups involved $3-$ 4 students at a time and lasted for 45-60 minutes. The interview questions were designed to focus on students' reflections about the task, rather than "right" and "wrong" answers or their own positioning on the welfare state (Ortiz, 2013).

Consequently, the material is quite extensive and offers diverse input to aid in understanding the processes that students were involved in during the module. However, these processes are subject to interpretation and, keeping the openendedness and diversity of classroom situations in mind, have their limitations (cf. Cohen et al., 2011, p. 189). In order to increase transparency, the data is analysed and discussed through the lens of Endacott and Brooks' (2013) three elements in order to examine what components are in play and how this affects students' reasoning. The analysis follows a chronological logic whereby the interventions are related to teaching before and after each of the tasks that students performed. In each section, the manifestation of the three elements (affective connections, contextualisation, and differential perspectives) is described and analysed. 


\section{The two interventions - Analysis and findings}

As previously discussed, the two tasks were designed to specifically promote students' academic SPT in order to address identified challenges that they faced in their understanding of the welfare state. The two tasks are presented and analysed separately and then compared and discussed in the conclusion.

\section{The first intervention - Examples from other contexts}

The first intervention was carried out during the seventh lesson (out of twelve) on welfare systems. By then, the teacher had covered the history of the Swedish welfare state, the financial system in relation to the welfare state (e.g., taxation and government spending), social security systems, and the challenges to the modern welfare state (e.g., demographics and austerity). These lessons were not just in the form of lectures, but included plenty of assignments addressing the topics of the lesson, e.g., analysing statistics about funding and spending in the Swedish welfare system.

The lesson in focus began with a short news documentary (SVT, 2016) about the welfare system in the USA. In contrast to the Swedish social-democratic system that students had been studying, the interviews in the documentary portrayed two different approaches to welfare: one from Washington State with (relatively to other US states) more general welfare and the second from Alabama, centring on individual responsibilities and private insurance. The intervention itself consisted of a ten-page handout containing short interviews with five different people from five different welfare states: Sweden, Canada, The USA, Switzerland and Germany. The interviews were compiled by the teacher and researcher and had been conducted via email with contacts in other countries. They were composed to illustrate a "typical case" in each country. The interviewees chosen for the handout were selected through a basic lens: they should be middle aged and have children in order to elicit answers that ensured knowledge through contact with their respective welfare system. The questions covered the following topics:

- Parental allowances

- Day-care for children

- Sick leave

- Financial support for higher education

- Pensions

- Taxation in relation to welfare

- Variations within the country

- The most discussed welfare topic in the media

- Their own views on their welfare system (i.e., whether they found their system to be just) 
The teacher instructed students to work in pairs and together read through the interviews and compare and discuss the similarities and differences portrayed in the handout. At the end of the 80-minute lesson, the teacher asked students to summarise their findings and reflections in their individual logbooks.

\section{Affective connections, contextualisation and differential perspectives}

The students' initial responses were very much emotional, with affective connections to their own beliefs. During the introduction, the documentary segments from Alabama sparked strong emotions from many of the students, one exclaiming "This is completely sick!" when an interviewed man questioned other systems for being too governmentally run. Overall, the class reacted with disbelief and antipathy to the documentary and, when it ended, the classroom became noisy with discussions. The teacher silenced the class and gave a short instruction before handing out the interviews.

During students' discussions of the handout, two of them had problems making sense of what they were reading about other countries' welfare regimes prompting an emotional response. It was also apparent that students tried to understand what they read by using their own experiences:

Student 1: Oh, my god! We're really spoiled when you look at the other countries. It seems extremely stressful to live in Switzerland for example.

Student 2: Yes, it's obvious how much we get... free healthcare, education...so much.

[...]

Student 1: We have friends in England, and they pay like 20,000 kronor each month for day-care, compared to what we pay... how much did it [the handout] say? 1500, right?

Student 2: That's crazy!

For these students, it appears natural to reflect new information against their own experiences and beliefs - in this case, bringing in a personal encounter with another welfare system. These kinds of responses were rather common in the logbooks as well. Some students were quick in their judgement of other systems and did not show curiosity to understand the context, but rather rushed to reject a system that was not to their liking. These extracts from different logbooks can serve as examples:

During the lesson we read interviews from different countries. I was surprised how stupid some systems are and how unequal it must be in those countries. (A8)

The conservative system lets religion play a big part. It's an old-fashioned ideology that's thick and unwilling to change. Women are supposed to be housewives and men should work. (A10)

What amazed me was how expensive basic things are, like education and kindergarten. Like Switzerland! That's just insane! And the cost of education in the USA is also bad. There are so many talented people who won't have the opportunity they're entitled to. [...] It's extremely unjust. (A27) 
The affective connections thus consisted of experiences from their own lifeworld and sparked emotions connected to their own belief systems. In these cases, emotions seemed to hinder students' ability to consider perspectives other than their own, and they became invested in taking a stand against other welfare systems. In many cases, they brought in their own understanding even where the handout did not include the stated information - the reference to religion in the conservative system above is one example. However, it seems clear that affective connections were just one component of their interactions with different welfare systems. One student wrote the following passage in her logbook, expressing emotions about what she had read, but at the same time attempting to contextualise the interviews:

What astonished me was how different it can be in different countries, this might sound silly but I can't understand why countries don't want a social-democratic welfare system that's good for everybody, and instead pick a system that risks leaving people outside society, which in the long run can create bigger problems. At the same time, I understand that different countries have their own history and that we think differently and that's why discussing this topic is so interesting and I just want to learn more about it. (A26)

This student attempted to make sense of the differences and, even though she had difficulties in understanding other perspectives and contexts, the affective connections became an important driver to understand more about welfare systems. The handout with examples from different countries thus intrigued many students and inspired them to inquire further about why the systems were different and what this means for societies in general. Not surprisingly, it was the liberal and conservative systems that confused and intrigued students the most. These two students tried to contextualise the interviews from liberal and conservative welfare regimes:

Today we saw examples from the different kinds of welfare models that I read about in the textbook before, the social-democratic, the liberal and the conservative. I didn't know that there were so many differences and was surprised that it's so expensive in many countries [...] the liberal model probably makes people look more for jobs, but I don't really think that people want to live on benefits. (A21)

It surprised me that it's so expensive for childcare in other countries, even though taxes are rather high. It probably has to do with other societal structures than we have, for instance that parents and grandparents are expected to take care of children. I was also surprised that work [employment] was so important in conservative systems and that people have to find jobs to get better welfare. (A2)

The handout did not give much information about the context in each country, e.g. the historical background of each welfare system, but students struggled to find clues as to why the systems were so different and what that meant. One pair of students tried to understand welfare in Switzerland (or in their words, the "lack of welfare") and why Switzerland had that particular system: 
Student 3: They really don't have that many benefits...

Student 4: No, but look at what she makes and how low the taxes are.

Student 3: What do you mean?

Student 4: She makes a ton of money and can pay for it [childcare]. She doesn't need benefits.

[...]

Student 4: It seems like the only benefits go to women... or mothers. It's like it's their job to take care of children [...] That's really different from our system...

Even though the students did not have all the relevant information, they found clues to understand the system they were investigating, in this case a conservative welfare state with more emphasis on women's traditional family role. However, during the intervention it was clear that students lacked important information about the context, which was given in the lesson after they had worked with the handout. The teacher then covered the three main welfare models according to Esping-Andersen's (1990) typology, i.e., the liberal, the conservative and the social-democratic. Students worked with the textbook and were expected to return to the handout and attempt to match each country to the typology they believed it most resembled. To scaffold their reading, the teacher handed out a matrix containing the three models and asked the students to continue working in pairs trying to find answers to questions in several categories: basic ideas behind each system, who had access to welfare benefits in each system, how it was funded, and how much of GDP was spent on welfare. Bringing in these contextual elements in teaching, became crucial for the students. One student reflected in the focus group interviews after teaching:

Researcher: So, what about the handout with interviews and the work you did with the matrix on different welfare models... How did that make you think about differences in how you can think about welfare?

Student: The interviews were really interesting to read... to learn about other countries. But it was also really confusing, and we were really shocked by some of the answers. But then to connect it to ideologies... then it all made sense... like the importance of families for conservatives. (Focus group 2)

In order to make sense of the interviews in the handout, students needed additional information. This was provided in the teacher's lecture, in the textbook and through students' work with the matrix. Without context, the students' experience became dominated by affective connections. As in the case of the documentary, students' discussions were mixed with disbelief about how much welfare systems can differ and how extensive the Swedish system is in comparison with many conservative and liberal examples in the handout. In many cases, the students struggled to understand why anyone wants to live in other kinds of systems, and in many cases they almost pitied the people who live in that system, thus failing to understand differential perspectives. However, the final interview question, where the interviewees presented their own view of their welfare system, became important for giving space to this element. In a discussion, one pair of students 
discovered that everyone was basically happy with their welfare model and found it to be just. In the follow-up focus group interviews, the researcher revisited this topic with three students:

Researcher: But you Jenny, saw that people were happy with their own welfare model. What did you think about that?

Student 1: I was confused by that. Maybe they don't know about other systems? They might be happy because they're ignorant?

Student 2: But it's the same for us, right? We don't know about their system and what they think? It's really hard to know what people think. And also, the interviews are just one person, right? One of them was rich and she has one opinion, and someone else probably disagrees. That's like true in every country.

Researcher: So, you're saying it's not obvious that everyone wants our kind of welfare system?

Student 2: Exactly. Some people want it to be traditional. Like the conservative model we talked about before [discussing the role of stay-at-home mothers]. They might not value the things I do.

Student 3: To me, it's about the role of government. You either want the state to take care of everything or you want people to fix everything themselves. (Focus group 2)

Apart from contextualising, the students displayed an ability to understand that not everyone had the same line of thinking and that it came down to the different values that people might have, i.e., they were reflexive and questioned their own position. In the excerpt above, context also appears important for making sense of differential perspectives, rather than just acknowledging them. Thus, contextualisation appears to be an element that nuances affective connections, as well as scaffolding differential perspectives.

\section{The second intervention - The fishbowl}

When students had completed their matrix of the three typologies, the teacher moved on to introduce the next task, the "fishbowl". This task aimed to underline the different kinds of values that might warrant support for one welfare model over another. Students were assigned to new groups, and each group was handed a "role card" for a specific political agenda. The role cards were entitled:

- More gender equality!

- More personal freedom and responsibilities for everyone!

- Corporations are the backbone of the country!

- Family first!

- We're all in this boat together!

The role cards gave a short explanation about each group's aim and what kinds of values they were supporting. Students were then given instructions to discuss the welfare model they supported and prepare themselves with arguments. Students had 30 minutes to prepare and decide before the fishbowl began in two mixed groups. There was no need for an extensive explanation of the proceedings 
because they had all used the method before. The idea of the fishbowl was that the student groups prepared to debate from a certain perspective on an issue and then sent representatives to mixed groups where they debated it together - thus ensuring that all positions were represented. The debate was performed with the representatives sitting on chairs in a circle (contained, as in a fishbowl) and only the members sitting down could talk. In order to enhance the dynamics, the student sitting in the chair also had members from their group standing behind them. Within the group, students could change the person on the chair at any time, i.e., if the member sitting down ran out of arguments, someone else could take over and position themselves in the fishbowl.

\section{Affective connections, contextualisation and differential perspectives}

The students began the assignment with enthusiasm and were eager to see which role they had been given. When they began reading their position and instructions, the affective connections became observable right from the start. Some groups displayed disappointment at being assigned to represent opinions they already held (the ones they interpreted as being in line with a social-democratic model) and others were happy about taking on positions far from their own. One student, appointed to the family-first group, exclaimed: "Yeah, let's go evil" (A6, cf. quotation below). Overall, students were enthusiastic both during and after the task and remembered it as the most uplifting and fun part of the entire welfare module. In their logbook, one student concluded:

It was a really good assignment. It's a really good way to learn through debating where you learn about different understandings and how ideologies think, instead of just reading about them on paper. You really had to get into the thinking of a conservative person. [...] I really learnt a lot. (A20)

However much fun the students thought it was, many of them displayed a perspective taking that was dominated by affective connections, especially in the form of taking a stand against the perspectives of the ideology they were assigned to support. One student, assigned to take on a conservative perspective, argued in the logbook:

The lesson today was without a doubt the most fun I've had in weeks. It was surprisingly easy to argue for "Family First!" You just had to say random things you hear from conservatives. Still, I wondered if conservatives really say these absurd things when I said them myself, they really are pushed to the extreme with "what, men can't take care of children". I leave school today in a happy mood and with insight into conservative absurdity. (A6)

In group preparations, students had no problems with getting into role and finding arguments from their given perspectives. As one student put it: they mostly "unconditionally argue for one point of view [and] sharpen your own arguments to make the arguments even better" (A22). In their work to refine the perspectives of liberal, conservative and social-democratic welfare systems, it seemed to 
scaffold their understanding and build further on the comprehension they had worked with in previous lessons. Still, the task itself did not encourage contextualisation in the same way as the previous task. One group discussed their assigned role "More personal freedom and responsibilities for everyone!" and quickly concluded that they were supposed to support a liberal system. However, the task itself encouraged a stereotypical understanding:

Student 1: We're liberal of course. It's all about the individual's right to keep their earnings. About the state not meddling in what individuals do. That you have the right to keep what you've done yourself. If you look out for your own interests, decisions are better. [...]

Student 2: That government shouldn't poke its nose into what people do... or don't do.

These stereotypical portraits of the welfare systems became apparent during the fishbowl segment when students began debating. In general, they did not listen to the arguments from the other side but focused on setting forth their own arguments and presenting their position in a stereotypical - and often antagonistic - way. Thus, the positions became straw men, rather than real positions. The following exchange, extracted from one of the groups in the fishbowl, illustrates this straw man effect:

Student 1: It really makes me upset that you can't see that your system forces women to stay at home.

Student 2: But we're protecting the rights of women!

Student 1: What?

Student 2: The right to stay at home! That's what they [women] are made for!

[...]

Student 3 [In a very theatrical voice]: It's so obvious that you [pointing at the member of "More gender equality!"] are all communists and want to control everything.

[Everyone starts to giggle]

In many cases, the exchanges in the debates ended with giggles and chuckles and it was clear that students were participating in a game, in which they competed to be the best debater. Many of the students distorted their voices and spoke as though they were enacting a theatrical scene. The competitive elements of the task left little room for contextualising the perspectives. It gave them a chance to refine and comprehend perspectives, but not to nuance or access the underlying beliefs and values that each perspective held. Instead, the perspectives became stereotypes. These simplifications were particularly prominent in groups portraying conservative or liberal welfare systems. Although, in many cases, students did try to find and understand the underlying arguments, they did not bring in enough contextualisation in order to do so:

It was obvious what kind of welfare system everyone was supporting, and it was really fun to see everyone get into their roles and argue for things they didn't believe in. I think this was a really good way to understand the arguments. Often you think like, hmmm, I wonder how conservatives and socialists think and now you got to see it in practice. 
You could really see their arguments, even if they were bad, when they stood their ground and argued for their views and goals. (A7)

However, the task itself seemed to stimulate students' ability to take on different perspectives and see merits in other students' arguments - even though their peers did not necessarily hold these views themselves. In many of the logbooks, students reflected on new arguments and how they had affected their own thinking:

It was really fun, and I got some new perspectives. One thing that I found extremely interesting was the discussion on selective or universal benefits. Perhaps it's better to give people benefits when they really need them instead of giving it to everyone? On the other hand, it's a good way to make people feel they're getting value for their taxes. (A3)

I thought it was really fun to debate this because it gave me insight into other perspectives than what I think, and see society in another way. [...] There are so many perspectives to choose from, like the one about the importance of jobs to the economy and then for society. Since I got to argue as a liberal, I wonder what the more cooperative or social-democratic arguments are [against this]. How do they think about this? I mean, corporations, that's where jobs come from right? (A11)

The fishbowl task itself appeared to provide insight into different perspectives and reveal that these can be valid from a different point of view that emphasises other values and societal goals. However, the competitive character of the task and the lack of contextualisation gave students little opportunity to understand the arguments in context. It became successful in illustrating the general differences between conservative, liberal and social-democratic arguments in relation to ideological positions, but these positions became stereotyped. Understanding different perspectives and contextualising them in this case seems to have more potential, as indicated by students in their logs.

\section{Discussion and conclusions}

With the aim of examining the components of SPT and how perspective taking can help students to open up one-sided viewpoints about political issues, this study investigated two different kinds of interventions. By using an adopted conceptualisation of social perspectives taken from Endacott and Brooks (2013), three different elements, affective connections, contextualisation and differential perspectives were used to analyse students' reflections. In this final section, the results of the interventions are compared and discussed in relation to teaching.

\section{Social perspective taking in the two interventions}

The point of departure in this study was that SPT can be understood through the three elements presented by Endacott and Brooks (2013), and that a combination 
of these elements can provide a more powerful experience for students. In the present study, the affective connections were prominent in both tasks that students performed during the module. The first intervention, the handout describing other contexts, immediately sparked emotions from students, who displayed disbelief and even disgust towards other ways of arranging welfare systems than the one they liked or had experience of, i.e. the social-democratic welfare model. Students generally had problems grasping that other people could (and wanted to) live in systems different from the Swedish one. In the other intervention, the fishbowl, students showed affective connections as well, but at the same time were more detached. The set-up of a role play seemed to soothe their feelings and their response was not as genuine or spontaneous as during the first intervention. This enabled them to distance themselves from their own political views. However, students' positioning became problematic when they adopted their assigned role, resulting in coarse simplifications and the stereotyping of political positions.

The element of affective connections was comprised of engagement, past experiences and emotions. In some ways, these affective connections could be seen as an impediment to the students' ability to practise SPT. Their own experiences and political beliefs became a strong force in their understanding, and they tended to dismiss other people's ideas or political belief systems as stupid, or even wicked. However, the affective connections are there and will play a role in students' encounters with political and controversial issues. Even though it might hinder their understanding in some cases, it is also an important drive to encourage interest and active citizenship (Parker, 2010a; Campbell, 2012; Barton, 2009). The results also suggest that, even though it is an important driver of interest, a focus on differential perspectives and contextualisation in teaching can challenge students and give them insight into other ways of understanding political issues.

The element of differential perspectives was also present in students' reflections both during the fishbowl and when reading the examples from other contexts. In the fishbowl, the different perspectives were exclusively expressed in the logbooks, where students reflected upon the arguments of others and displayed an understanding that there can be valid opinions and reasoning from other vantage points. During the fishbowl debate, differential perspectives were hampered by the competitive nature of the assignment. In the first intervention, differential perspectives were blatantly overshadowed by students' disbelief about how different the levels of subsidies could be in the three welfare models. However, this element of social perspective taking became explicit when students understood that people in other systems might find their own system just.

The most essential element in both interventions was contextualisation (or lack thereof), which appeared to facilitate the element of differential perspectives and to nuance affective connections. In the first intervention, students' reasoning became more thoughtful and reflective when they could connect the interviews to the typology of conservative, liberal and social-democratic welfare regimes. When the issue was raised to a more structural level (e.g., ideology), it seemed 
easier for students to look beyond the individual perspectives in the handout and understand how others might reason from a different contextual setting. Even though they did not change their own point of view, the students could see that others might argue just as hard for their position as they did themselves and that this was related to ideological or cultural settings - thus, contextualisation appeared to scaffold differential perspectives. Here, content matter in the form of Esping-Andersen's (1990) typology, paired with the interviews and the matrix, resulted in a more powerful experience than in the second intervention. The second intervention gave students an opportunity to explicitly see the differences between the welfare models and in a way to clarify the ideological context. Nevertheless, the ideologies became stereotyped and the debate itself became more important than the context.

To conclude, the results suggest that SPT interventions can play a role in increasing students' understanding of controversial and political issues in a way that is in line with the literature on citizenship education (Campbell, 2012; Parker, 2010b), as well as more specific research on social perspective taking (Gehlbach, 2004; Gehlbach et al., 2012; Gehlbach et al., 2015). The study also affirms previous research highlighting the importance of context (Vescio et al., 2003; Todd et al., 2012; Wang et al., 2014). When students participated in a competitive task (the fishbowl), it resulted in stereotyping - ideological standpoints became caricatures rather than valid perspectives to be understood, thus confirming Pierce et al.'s (2013) results from experimental settings.

This study provides encouragement to continue research into the role of contextualisation, which appears to be crucial to students' development of reflective capacities and helps them to open up their own political views and contrast them with other viable views on how societies could and should function. When the task focused on contextualisation, students' understanding displayed more reflexive and qualified reflections.

\section{Implications for teaching - How do we promote social perspective taking?}

In this study, it seems clear that affective connections were an important motivation that increased students' engagement in class. Students often highlighted the role playing in the fishbowl as the most memorable and fun part of the module on the welfare state, and this was the most vibrant lesson. With the results of this study in mind, that the competitive nature of the fishbowl resulted in stereotyping, I would argue that competitive tasks such as the one employed here (and probably transferable to other forms of competitive assignments) are of doubtful value as a means to achieve social perspective taking - however much appreciated they may be from a student perspective. In the collaborative task, differential perspectives and contextualisation became important tools for understanding other perspectives.

In order to promote SPT, teaching needs to place greater emphasis on contextualisation and differential perspectives in order to provide students with 
sufficient information to be able to understand perspectives other than those they hold themselves or from their own context. Inspired by the work in history education, particularly that of Peter Seixas (Seixas \& Morton, 2013, p. 148), I would suggest four guiding principles for social perspective taking in social science education. These could be helpful in planning activities in class to foster SPT:

Guiding principle 1: Social perspective taking includes understanding other actors and societies, not identification or sympathy; students need to move from judging other systems from their own point of view, to a more powerful understanding whereby they can temporarily disregard their own views.

Guiding principle 2: Perspectives are differential, i.e., different actors have diverse perspectives within a given setting that might seem homogeneous to an outsider; students need to move from an assumption that everyone in a particular societal context has the same view on an issue, to a more powerful understanding by which they can distinguish a variety of perspectives.

Guiding principle 3: The perspectives of other actors are best understood through contextualisation, i.e., ideological and cultural contexts; students need to move from an outset where they understand the world from their own familiar context and their own beliefs, to a more powerful understanding enabling them to inquire into other societal contexts, belief systems and ideas.

Guiding principle 4: Social perspective taking involves reflexivity, i.e., an awareness of one's own values, motives and convictions; students need to move from the premise that everyone thinks as they do (and if not, they are irrational or stupid), to a more powerful understanding with which they scrutinise their own beliefs and contrast them with those of "the other".

The guiding principles discussed here are closely linked to disciplinary thinking in the social sciences, i.e., the ways in which social scientists go about making sense of different perspectives on social issues (Sandahl, 2015a; cf. Barton, 2017). As such, the principles are related to theory, previous research and the findings of this study. Principle one relates to academic SPT in its focus on actors rather than individuals (Gehlbach \& Brinkworth, 2012), while the second highlights the fact that perspectives can be different within societies and groups (Endacott \& Brooks, 2013). The third principle relates to findings in previous research that are emphasised in the results reported in this article: that contextualisation is crucial. Also, the fourth principle is highlighted in the results. In order to understand others, students need to scrutinise their own views. However, the principles leave out one important piece of the puzzle: affective connections.

This study demonstrates that affective connections are present in teaching if controversial and political issues are dealt with and this does not need scaffolding by the teacher. If we want to promote SPT, I would argue, teaching should revolve around contextualisation and differential perspectives in order to nuance and qualify students' own experiences and beliefs. This does not mean that the 
affective connections are useless or that they hinder students' development of SPT. Emotions and political identity will always be present and are important to stimulate interest, engagement and meaning making. However, if we want to contribute to students' citizenship education and give them tools to tackle onesided viewpoints about the good society, we need to challenge their views. In this process, contextualisation and differential perspectives are important.

\section{About the author}

Johan Sandahl, $\mathrm{PhD}$, is a senior lecturer in social science education and head of the Research Group in Social Science (Samhällskunskap) at Stockholm University. His main research interest is the role that social science education can play in citizenship education.

Institutional Affiliation: Department of Humanities and Social Sciences Education, Stockholm University, 10691 Stockholm, Sweden.

Email: johan.sandahl@hsd.su.se

\section{References}

Alongi, M. D., Heddy, B. C., \& Sinatra, G. L. (2016). Real-world engagement with controversial issues in history and social studies: Teaching for transformative experiences and conceptual change. Journal of Social Science Education, 15(2), 26-41.

Alsop, S. (2016). Encountering science education's capacity to affect and be affected. Cultural Studies of Science Education, 11(3), 551-565.

Amnå, E. (2012). How is civic engagement developed over time? Emerging answers from a multidisciplinary field. Journal of Adolescence, 35(3), 611-627.

Barton, K. C. (2009). The denial of desire: How to make history education meaningless. In L. Symcox \& A. Wilschut (Eds.), National history standards: The problem of the canon and the future of teaching history (pp. 265-282). Greenwich, CT: Information Age Publishing.

Barton, K. C. (2011). Wars and rumors of war: Making sense of history education in the United States. In T. Taylor \& R. Guyver (Eds.), History wars in the classroom: Global perspectives (pp. 187-202). Charlotte, NC: Information Age Publishing.

Barton, K. C. (2015). Elicitation techniques: Getting people to talk about ideas they don't usually talk about. Theory and Research in Social Education, 43(2), 179-205.

Barton, K. C. (2017). Shared principles in history and social science education. In M. Carretero, S. Berger, \& M. Grever (Eds.), Palgrave handbook of research in historical culture and education (pp. 449-467). London: Palgrave Macmillan.

Barton, K. C., \& Levstik, L .S. (2004). Teaching history for the common good. Mahwah, NJ: Lawrence Erlbaum Associates.

Barton, K. C., \& McCully, A. (2007). Teaching controversial issues... where controversial issues really matter. Teaching History, 127, 13-19.

Bauman, Z., \& Obirek, S. (2015). On the world and ourselves. Cambridge: Polity.

Brooks, S. (2009). Historical empathy in the social studies classroom: A review of the literature. Journal of Social Studies Research, 33(2), 213-234. 
Bunar, N. (2010). The controlled school market and urban schools in Sweden. Journal of School Choice, 4(1), 47-73.

Campbell, D. E. (2012). Introduction. In D. E. Campbell, M. Levinson, \& F. M. Hess (Eds.), Making Civics Count: Citizenship Education for a New Generation (pp. 1-14). Cambridge, MA: Harvard Education Press.

Chichekian T., \& Shore, B. M. (2017). Hold firm: Gifted learners value standing one’s ground in disagreements with a friend. Journal for the Education of the Gifted, 40(2), 152-167.

Christensen, T. S. (2011). Educating citizens in late modern societies. In B. Schüllerqvist (Ed.), Patterns of research in civics, history, geography and religious education: Key presentations and responses from an international conference at Karlstad University, Sweden 2010 (pp. 37-51). Karlstad: Karlstad University Press.

Cohen, L., Manion, L., \& Morrison, K. (2011). Research methods in education. Abingdon, Oxon: Routledge.

Davis, O. L., Yeager, E. A., \& Foster, S. J. (Eds.) (2001). Historical empathy and perspective taking in the social studies. Lanham, MD: Rowman \& Littlefield.

Delamont S. (2011). Ethnographic methods in education. New York: Sage.

Endacott, J., \& Brooks, S. (2013). An updated theoretical and practical model for promoting historical empathy. Social Studies Research and Practice, 8, 41-58.

Englund, T. (2006). Deliberative communications: A pragmatist proposal. Journal of Curriculum Studies, 38(5), 503-520.

Esping-Andersen, G. (1990). The three worlds of welfare capitalism. Cambridge: Polity Press.

Gehlbach, H. (2004). Social perspective taking: A facilitating aptitude for conflict resolution, historical empathy, and social studies achievement. Theory \& Research in Social Education, 32(1), 39-55.

Gehlbach, H. (2011). Making social studies social: Engaging students through different forms of social perspective taking. Theory into Practice, 50, 311-318.

Gehlbach, H., \& Brinkworth, M. E. (2012). The social perspective taking process: Strategies and sources of evidence in taking another's perspective. Teachers College Record, 114(1), 226-254.

Gehlbach, H., Brinkworth, M. E., \& Wang, M.-T. (2012). The social perspective taking process: What motivates individuals to take another's perspective? Teachers' College Record, 114(1), 197-225.

Gehlbach, H., Brown, S. W., Ioannou Gehlbach, H., Marietta, G., King, A. M., Karutz, C., Bailenson, J. N., \& Dede, C. (2015). Many ways to walk a mile in another's moccasins: Type of social perspective taking and its effect on negotiation outcomes. Computers in Human Behavior, 52, 523-532.

Gutmann, A., \& Ben-Porath, S. (2015). Democratic education. In M. T. Gibbons (Ed.), The encyclopedia of political thought (pp. 1-12). Hoboken, NJ: John Wiley \& Sons.

Hartmann, U., \& Hasselhorn, M. (2008). Historical perspective taking: A standardized measure for an aspect of students' historical thinking. Learning and Individual Differences, 18, 264-270.

Hess, D. E. (2009). Controversy in the classroom: The democratic power of discussion. New York: Routledge.

Huddy, L. (2001). From social to political identity: A critical examination of social identity theory. Political Psychology, 22(1), 127-156.

Kildal, N., \& Kuhnle, S. (Eds.) (2005). Normative foundations of the welfare state: The Nordic experience. New York: Routledge.

Lee, P., \& Ashby, R. (2001). Empathy, perspective taking, and rational understanding. In O. L. Davis, E. A. Yeager, \& S. J. Foster (Eds.), Historical empathy and perspective taking in the social studies (pp. 21-50). Lanham, MD: Rowman \& Littlefield. 
Misco, T. (2012). The importance of context for teaching controversial issues in international settings. International Education, 42(1), 69-84.

Ortiz, A. M. (2013). The ethnographic interview. In F. K. Stage \& K. Manning (Eds.), Research in the college context: Approaches and methods (pp. 45-48). New York, NY: Routledge.

Parker, W. C. (2010a). Idiocy, puberty, and citizenship. In W. C. Parker (Ed.), Social studies today: Research and practice (pp. 247-260). New York, NY: Routledge.

Parker, W. C. (2010b). Social studies education eC21. In W .C. Parker (Ed.), Social studies today: Research and practice (pp. 3-13). New York: Routledge.

Pierce, J. R., Kilduff, G. J., Galinsky, A. D., \& Sivanathan, N. (2013). From glue to gasoline: How competition turns perspective takers unethical. Psychological Science, 24(10), 1986-1994.

Ross, A. (2019). Finding political identities: Young people in a changing Europe. Cham, Switzerland: Springer International.

Sandahl, J. (2015a). Preparing for citizenship: The value of second order thinking: Concepts in social science education. Journal of Social Science Education, 14(1), 19-30.

Sandahl, J. (2015b). Civic consciousness: A viable concept for advancing students' ability to orient themselves to possible futures? Historical Encounters, 2(1), 1-15.

Sandahl, J. (2015c). Medborgarbildning i gymnasiet: ämneskunnande och medborgarbildning i gymnasieskolans samhälls- och historieundervisning [Citizenship education in upper secondary school: Subject knowledge and citizenship education in history and social science education]. Stockholm: Stockholm University.

Sandahl, J. (2019). Studying politics or being political? High school students' assessment of the welfare state. Journal of Social Science Education, 18(1), 153-171.

Seixas, P., \& Morton, T (2013). The Big Six Historical Thinking Concepts. Toronto: Nelson Education.

Skorinko, J. L., \& Sinclair, S. A. (2013). Perspective taking can increase stereotyping: The role of apparent stereotype confirmation. Journal of Experimental Social Psychology, 49(1), 10-18.

Svallfors, S. (2011). A Bedrock of support? Trends in welfare state attitudes in Sweden, 1981-2010. Social Policy \& Administration, 45(7), 806-825.

SVT (2016). Två familjer, två samhällsvisioner [Two families, two visions]. Svt-play, SVT: https://www.svtplay.se/klipp/6021375/tva-familjer-tva-samhallsvisioner . Visited 201603-18.

Swedish National Agency for Education (2011). Social studies. Stockholm: Swedish National Agency for Education. https://www.skolverket.se/download/18.4fc05a3f164131a74181078/1535372299998/Soci al-studies-swedish-school.pdf

Tarrant, M., Calitri, R., \& Weston, D. (2012). Social identification structures the effects of perspective taking. Psychological Science, 23(9), 973-978.

Todd, A. R., Galinsky, A. D., \& Bodenhausen, G. V. (2012). Perspective taking undermines stereotype maintenance processes: Evidence from social memory, behavior explanation, and information solicitation. Social Cognition, 30(1), 94-108.

Vaughn, S., Schumm, J. S., \& Sinagub, J. (2012). Focus group interviews in education and psychology. Thousand Oaks, CA: Sage.

Vescio, T. K., Sechrist, G. B., \& Paolucci, M. P. (2003). Perspective taking and prejudice reduction: The mediational role of empathy arousal and situational attributions. European Journal of Social Psychology, 33(4), 455-472. 
Walker, C. L., Shore, B. M., \& Tabatabai, D. (2013). Eye of the beholder: Investigating the interplay between inquiry, role diversification and social perspective taking. International Journal of Educational Psychology, 2(2), 144-192.

Wang, C. S., Kenneth, T., Ku, G., \& Galinsky, A .D. (2014). Perspective-taking increases willingness to engage in intergroup contact. PloS One, 9(1), 1-8. 